\title{
EFFECT OF ASPARTAME AND SUCROSE ON SOME BIOCHEMICAL AND HAEMATOLOGICAL PARAMETERS IN WISTAR ALBINO RATS
}

\author{
G.O. OBOCHI, S. P. MALU, N.O. ALOBI, A. I. IYAM AND Y.ALOZIE \\ (Received 19, August 2008; Revision Accepted 12, December 2008)
}

\begin{abstract}
Effect of aspartame and sucrose on some biochemical and haematological parameters in wistar albino rats was studied. Sixteen rats were randomly assigned into four study groups. The rats in group 1, received a placebo of $5.0 \mathrm{ml}$ distilled water via gastric intubation. The animals in groups 2 through 4 were treated with $100 \mathrm{mg}$ aspartame/kg, $100 \mathrm{mg}$ sucrose $/ \mathrm{kg}$, or a combination of $100 \mathrm{mg}$ aspartame $/ \mathrm{kg}+100 \mathrm{mg}$ sucrose $/ \mathrm{kg}$, respectively, in a total volume of $5.0 \mathrm{ml}$ vehicle. The experiment lasted for 30days. One day after the final exposure, the animals were euthanized by inhalation of overdose of chloroform. Blood was collected by cardiac puncture into EDTA sterilized sample bottles. Protein free blood was prepared and used for the analysis of glucose while whole blood was used for hemoglobin and hematocrit analysis; serum was prepared by centrifugation and used for serum total protein levels. The brain of each rat was also harvested and processed into whole homogenate and used for the analysis of brain tryptophan and phenylalanine levels. The results showed that consumption of aspartame and sucrose inhibited protein and leukocytes synthesis, resulting in anemia, and bone marrow hypoplasia, and DNA dysfunction. The results also showed that aspartame and sucrose consumption inhibited hexokinase, resulting in inhibition of glucose uptake by hepatic tissues, leading to hypoglycemia, which has been linked with aggressive and violent behaviours, diverse personality, and psychiatric disorders such as neuroses, panic attacks, agoraphobia and schizophrenic episodes as well as neuronal disorders.
\end{abstract}

The alterations had led to changes in behaviours including aggressive and violent behaviours .those foods seemed greatly to increase their restless and destructive behaviour of susceptible individuals.

KEYWORDS: Aspartame, Sucrose, Food additives, behaviour, Immunotoxicity.

\section{INTRODUCTION}

Aspartame and Sucrose are food additives widely used as sweeteners in soft drinks and sweet foods. The main ingredient in aspartame is the amino acid, phenylalanine (Ross, 1988; Wynn, 1994). Food additives are chemicals or substances that are added to foods to preserve or enhance its properties, maintain or improve its nutritive value, maintain freshness and or help in processing. Chemical additives have been in use for decades; the salts are used for curing, yeast and baking powder as leavening in baked foods, calcium silicate and magnesium stearate as anticaking agents, to prevent lumps in dry mixers, humectants such as glycerol, propylene glycol, and sorbitol, to help retain moisture in breads and cakes, emulsifiers such as egg yolk, lecithin and monoglycerides, which bind oil and water, help improve the uniformity and smoothness of foods while stabilizers and thickeners such as guargum, carragenam, curry, thyme, and gelatin, help preserve foods by preventing or slowing chemical changes, thereby inhibiting the growth of microorganisms (Weiss, 1984; Smith, 1991; Young, 1994).

Sucrose (table sugar) is a simple molecular substance, artificially refined from complex carbohydrates; and it is contained in most foods. It has been directly associated with high incidence of both criminal and anti social behaviour (Van Praag, 1986; Goldman, 1986). An excessive refined carbohydrate consumption could also lead in susceptible individuals to a disordered carbohydrate metabolism, especially to reactive hypoglycemia, which in turn, has been found to be particularly prevalent among violent offenders (Fisherman, 1982; Galler, 1986). Reactive hypoglycemia has also been linked with diverse personality and psychiatric disorders such as neuroses, panic attacks, agoraphobia and Schizophrenic episodes (Virkkuken, 1986).

As the use of food additives has grown, so has the public concern about the type and amounts of these additives and their toxic potential in humans. Thus, their popularity in public foods has aroused considerable medical interest. The growth in the use of food additives has also increased the consumption of these food additives, with considerable data linking food additive intolerance with physical and mental disorders as well as reproductive dysfunction (Ward,1990; Smith, 1991; Bryce-Smith, 1994, Young, 1994). This current study focused on the assessment of how consumption of aspartame and Sucrose could impact upon behavioral pattern and associated immunotoxicity in wistar albino rats exposed daily to these additives.

G. O. Obochi, Department of Chemistry/ Biochemistry, Cross River University of Technology, P.M.P 1123 Calabar.

S. P. Malu, Department of Chemistry/ Biochemistry, Cross River University of Technology, P.M.P 1123 Calabar.

N. O. Alobi, Department of Chemistry/ Biochemistry, Cross River University of Technology, P.M.P 1123 Calabar.

A. I. Iyam, Department of Chemistry/ Biochemistry, Cross River University of Technology, P.M.P 1123 Calabar.

Y. Alozie, Department of Chemistry/ Biochemistry, Cross River University of Technology, P.M.P 1123 Calabar. 


\section{MATERIALS AND METHODS}

\section{EXPERIMENTAL ANIMALS}

Sixteen wistar albino rats weighing between 180-300g obtained from the disease free stock of the animal house, Department of Biochemistry, College of Medical Sciences, University of Calabar, Nigeria were used for the study. The animals were randomly assigned into four study groups of four animals per group. Each rat in a study group was individually housed in a stainless cage with plastic bottom grid and a wire screen top. The animal room was adequately ventilated,, and kept at room temperature and relative humidity of $29 \pm 2^{\circ} \mathrm{C}$ and $40-70 \%$ respectively with 12 hour natural light-dark cycle. The animals were fed ad libitum with water and rat chow (Livestock feeds Ltd, Calabar, Nigeria). Good hygiene was maintained by constant cleaning and removal of faeces and spilled feeds from cages daily. All animal experiments were approved by the Animal care and use Committee of the Medical College, University of Calabar, Nigeria.

\section{Treatment Regimen}

All rats received daily treatment with their test solutions for a period of 30 days. All treatments were conducted between the hours of 9.00-10.00Am. The rats in Group 1 (control) received a placebo of $5.0 \mathrm{ml}$ distilled water via gastric intubation. The rats in groups 2 through 4 were treated with $100 \mathrm{mg}$ aspartame $/ \mathrm{kg}$, $100 \mathrm{mg}$ sucrose $/ \mathrm{kg}$, or a combination of $100 \mathrm{mg}$ aspartame $/ \mathrm{kg}+100 \mathrm{mg}$ sucrose $/ \mathrm{kg}$, respectively, in a total volume of $5.0 \mathrm{ml}$ vehicle.

\section{Preparation of Aspartame}

Synthetic aspartame was obtained from Marian Market (Calabar, Nigeria) for use in the study. A stock solution was prepared by dissolving $20 \mathrm{~g}$ powdered aspartame in $500 \mathrm{ml}$ distilled water. From this, and based on the animal's weight that morning, the $100 \mathrm{mg} / \mathrm{kg}$ dosages were administered to the animals in groups 2 and 4 as part of the $5.0 \mathrm{ml}$ volume used for gastric intubation.

\section{Preparation of Sucrose}

Synthetic Sucrose (table sugar) was obtained from Marian Market (Calabar, Nigeria) for use in the study. A stock solution was prepared by dissolving $20 \mathrm{~g}$ powdered sucrose in $500 \mathrm{ml}$ distilled water. From this, and based on the animals weight that morning, the $100 \mathrm{mg} / \mathrm{kg}$ dosages were administered to the animals in groups 3 and 4 as part of the $5.0 \mathrm{ml}$ volume used for gastric intubation.

\section{Preparation of Samples}

One day after the final exposure, the animals were euthanized by inhalation of overdose chloroform. Blood was collected by cardiac puncture into EDTA sterilized sample bottles. Protein free blood (filtrate) was prepared and used for the analysis of glucose, while whole blood was used for hemoglobin, and hematocrit analysis. Serum was also prepared by centrifugation $(6000 \times \mathrm{g}, 30 \mathrm{~min})$ and used for serum total protein levels. The brain of each rat was also harvested and processed into whole homogenate and used for the anaiysis of brain trypotophan and phenylalanine levels.

\section{Determination of serum total protein}

Serum total protein was determined by the Biuret method described by lowry et al (1951) which represents modifications of the Gornall et al (1949). Briefly, tubes 1-8 were set, $0.1,0.2,0.4,0.6,0.8,1.0$ and $1.2 \mathrm{ml}$ of the protein solution were pipetted into tubes 2 through 8 , respectively. Also 1.4, 1.3, 1.1, 0.9, $0.7,0.5$, and $0.3 \mathrm{ml}$ distilled water was added to tubes 2 through 8 , respectively to bring volume to $1.5 \mathrm{ml}$ in each tube. Tube 1 (the blank) received $1.5 \mathrm{ml}$ distilled water. The suspension was mixed, and $0.2 \mathrm{ml} 5 \%$ sodium deoxycholate (DOC) in $0.01 \mathrm{~N} \mathrm{KOH}$ was added and mixed to make the suspension more soluble. Then, $1.5 \mathrm{ml}$ of burette reagent $\left(1.50 \mathrm{~g} \mathrm{CuSo} 4.5 \mathrm{H}_{2} \mathrm{O}, 6.0 \mathrm{~g}\right.$ Sodium potassium tartarate and $300 \mathrm{ml}$ of $10 \% \mathrm{NaOH}$ per litre) was added (including the blank). The tubes were mixed in a vortex mixer, and incubated at $37{ }^{\circ} \mathrm{C}$ for $15 \mathrm{~min}$, and the absorbance were read at $540 \mathrm{~nm}$ against the blank (tube 1) in a 6400/6405 spectrophotometer (Jenway, Essex, England). The concentration of the standard bovine serum albumin (BSA) was $2 \mathrm{mg} / \mathrm{ml}$.

\section{Determination of Blood Glucose}

Blood glucose was determined by the method of Folin and Wu described by Taylor (1989).Protein free blood was prepared by pipetting $2.5 \mathrm{ml}$ of whole blood (heparinized blood into a 125-ml flask). Then, $17.5 \mathrm{ml}$ distilled water was added and mixed by swirling, after which $2.5 \mathrm{ml}$ of $10 \% \mathrm{Na}$ tungstate solution $(100 \mathrm{~g} \mathrm{Na}$ tungstate in $\mathrm{H}_{2} \mathrm{O}$ and diluted to $1 \mathrm{~L}$ ) was added, and mixed by swirling. Then, $2.5 \mathrm{ml}$ of $0.67 \mathrm{~N} \mathrm{H}_{2} \mathrm{SO}_{4}$ was added dropwise with continuous swirling, shooked gently and allowed to stand for $10 \mathrm{~min}$. The suspension was then filtered through Whatman filter paper (No.2), and the clear filtrate (protein-free blood) was collected.

Test tubes (1-8) were set and $1.0 \mathrm{ml}$ of the protein-free blood (filtrate) were pipetted into tubes 2 through 4 while tubes 5 through 8 received glucose standard $(10.0 \mathrm{mg} / \mathrm{ml}$ glucose stock standard - ie dissolved $1.0 \mathrm{~g}$ glucose in $100 \mathrm{ml}$ of $\mathrm{H}_{2} \mathrm{O}$ of volume $0.1,0.2,0.4$ and $0.6 \mathrm{ml}$, respectively), and these volumes were brought to $0.1 \mathrm{ml}$ with distilled water. Tube1 (the blank) received $1.0 \mathrm{ml}$ distilled water. Then, $1.0 \mathrm{ml}$ alkaline copper reagent (40 anhydrous $\mathrm{Na}_{2} \mathrm{CO}_{3}$ in $800 \mathrm{ml}$ $\mathrm{H}_{2} \mathrm{O}$, added $7.5 \mathrm{~g}$ tartaric acid, stirred until dissolved. Then, added $4.5 \mathrm{~g} \mathrm{CuSO}_{4} .5 \mathrm{H}_{2} \mathrm{O}$ and stirred and diluted to IL with $\mathrm{H}_{2} \mathrm{O}$ ) added to all test tubes. The suspension was heated in a water bath for $8 \mathrm{~min}$, and cooled on ice. Then, $1.0 \mathrm{ml}$ of phosphomolybdic acid solution (dissolved $70 \mathrm{~g}$ molybdic acid, $10 \mathrm{~g}$ Na tungstate, and $40 \mathrm{~g}$ $\mathrm{NaOH}$ in $650 \mathrm{ml} \mathrm{H} 20$. Then, $250 \mathrm{ml}$ conc. $\mathrm{H}_{3} \mathrm{PO}_{4}$ was slowly added and diluted to $\mathrm{IL}$ with $\mathrm{H}_{2} \mathrm{O}$ ) and slowly added to all test tubes.Further, $7.0 \mathrm{ml}$ distilled water was added to all test tubes, mixed and the absorbances read at $4200 \mathrm{~nm}$ using 640016405 spectrophotometer(Jenway, Essex,England)against the reaction blank. The concentration of the standard glucose was $0.2 \mathrm{mg} / \mathrm{ml}$ (Diluted $2 \mathrm{ml}$ stock glucose $(10.0 \mathrm{mg} / \mathrm{ml})$ standard to $100 \mathrm{ml}$ with $\mathrm{H}_{2} \mathrm{O}$ ).

\section{Determination of Hemoglobin}

Hemoglobin was determined by the cyanomethemoglobin method described by Taylor (1989).Briefly, $20 \mu$ l of whole blood were pipetted into 
tubes 2 through 4 while tube 1 (the blank) received $20 \mu \mathrm{l}$ distilled water, and $5.0 \mathrm{ml}$ potassiumferricyanide solution $\left(1.0 \mathrm{~g} \mathrm{NaHCO} 3,50 \mathrm{mgKCN}\right.$ and $200 \mathrm{mg} \mathrm{K}_{2} \mathrm{Fe}(\mathrm{CN})_{6}$ in $1 \mathrm{~L}$ )was added to all tubes, covered with paraffin and gently mixed. The tubes were incubated at $37^{\circ} \mathrm{C}$ for $10 \mathrm{~min}$, and the absorbance read at $540 \mathrm{~nm}$ in 6400164005 spectrophotometer (Jenway, Essex, England) against a reaction blank.

\section{Determination of Haematocrit}

Hematocrit was determined using standard method described by Taylor (1989). A capillary tube was filled with whole blood and spun in a centrifuge to pack the red blood cell (RBCs). The hematocrit value was calculated as the ratio of height of cell over the total height of fluid in the tube. A hematocrit tube was filled by capillary action to the mark with whole blood while the pack bottom end of the capillary tube was filled with clay. This procedure was repeated for the second hematocrit tube. The two tubes were centrifuged at $4000 \mathrm{xg}$ for $5 \mathrm{~min}$ against each other and the percent cell volume read by sliding the tube along a critocap chart until the meniscus of the plasma intersected the $100 \%$ line. The average value (triplicate) was recorded.

\section{Determination of brain trytophan}

Whole homogenates of the brain tissues were prepared using the stardard method described by Davidson and Henry (1979).Brain tissues were ground using mortar and pestle, buffered with $0.1 \mathrm{M}$ phosphate buffer, $\mathrm{pH}$ 7.0. The suspension was centrifuged at $6000 \mathrm{xg}$ for $30 \mathrm{~min}$, and the insoluble debris discared; $1.0 \mathrm{ml}$ of each supernatant were pippeted into $20 \mathrm{ml}$ amples, 9.0ml 6.0N NaOH added, mixed, and ampule sealed by pulling the glass tip over an intense flame. The suspension was incubated at $110^{\circ} \mathrm{C}$ for $24 \mathrm{hrs}$. The extracts was transferred to $50-\mathrm{ml}$ beakers, and titrated each with $6 \mathrm{~N} \mathrm{HCL}$ to $\mathrm{pH} 7.0$ while mixing on a magnetic stirrer. The titration was then changed to $\mathrm{IN} \mathrm{HCl}$ at a pH 8.5 , and then centrifuged at $10,000 \times \mathrm{g}$ for $20 \mathrm{~min}$. The supernatant was decanted into $25-\mathrm{ml}$ graduated cylinders, and the volumes brought to $20 \mathrm{ml}$ with $0.1 \mathrm{M}$

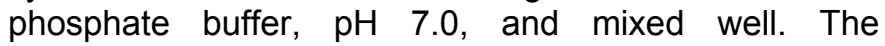
hydrolysate (whole homogenate $-\mathrm{WH}$ ) was used for the analysis of brain trypotophan levels.

Brain tryptophan was determined using the standard method described by Davidson and Henry (1979). About $1.0 \mathrm{ml}$ of trypotophan solution (200ug/ml) was pipetted into tubes 2 through 7 for the standard curve, while tube1 (the blank) received $1.0 \mathrm{ml}$ distilled water. Then, $5 \mathrm{ml}$ of tryptophan free growth medium (per L K ${ }_{2} \mathrm{HPO} 4,10.5 \mathrm{~g} \mathrm{KH}_{2} \mathrm{P} 04,4.5 \mathrm{~g}$; $\left.\mathrm{NH}_{4}\right] 2$ SO4, 1.0g; $\mathrm{Na}$ citrate.2H20,1.0g; $\mathrm{Mg} \mathrm{S04}, 0.05 \mathrm{~g}$; glucose, $2 \mathrm{~g}$ ) was added to all tubes, and $5 \mathrm{ml} 4 \%$ glucose solution added. The tubes were autoclaved for $15 \mathrm{~min}\left(120^{\circ} \mathrm{C}\right.$; $15-1 \mathrm{~b}$ pressure). All the tubes were allowed to cool to room temperature, and incubated in a shaking water bath at $37^{\circ} \mathrm{C}$ for $48 \mathrm{hr}$. The tubes were mixed vigorously in a vortex mixer and absorbances read at $450 \mathrm{~nm}$ in 640016405 spectrophotometer (Jen way, Essex, England) against the blank.

\section{Determination of brain phenylalanine}

Brain phenylalanine was determined with modification of the method of MCCaman and Robins
(1962). About $0.50 \mathrm{ml}$ of the whole homogenates prepared (described earlier) were transferred to $1.5-\mathrm{ml}$ microfuge tube, and $0.55 \mathrm{ml} 6 \mathrm{~N} \mathrm{HCl}$ added mixed, and incubated at $37^{\circ} \mathrm{C}$ for $5 \mathrm{~min}$. The suspension was centrifuged $(6000 \mathrm{xg}, 10 \mathrm{~min})$ in a microfuge, and the supernatant transferred into new tubes. Then, 20, 30 and $40 \mu \mathrm{l}$ of the supernatant were pipetted into tubes 2 , 3 , and 4 , respectively. Tube 1 (the blank) received $10 \mu \mathrm{l}$ distilled water. Each whole homogenate (WH)(hydrolysate) represented $10 \mathrm{mg} / \mathrm{ml}$ phenylalamine extract.Then, $16 \mathrm{ml}$ of reagent mix $(10 \mathrm{ml}$ $0.3 \mathrm{M}$ succinate buffer, $\mathrm{pH} 5.8,4 \mathrm{ml} 30 \mathrm{mM}$ ninhydrin and $2 \mathrm{ml} 5 \mathrm{mM}$ I-leucyl-I-alanine) was added to each tube. $2 \mathrm{ml} 0.3 \mathrm{~N}$ and $0.6 \mathrm{~N}$ TCA was added to each tube. The suspension was then incubated at $60^{\circ} \mathrm{C}$ for $2 \mathrm{hr}$, and then allowed to cool to temperature. Then, $5 \mathrm{ml}$ of copper reagent (1.6g Na $\mathrm{Na}_{3}, 0.1 \mathrm{~g} \mathrm{kNaC} \mathrm{CH}_{4} \mathrm{O}_{6} .4 \mathrm{H}_{2} \mathrm{O} 6.4 \mathrm{H}_{2} \mathrm{O}$, $0.06 \mathrm{G}$ CuSO4. $5 \mathrm{H} 20$ in 1 Litre $\mathrm{H} 20$ ) was added, mixed, and the tubes were incubated at $37^{\circ} \mathrm{C}$ for $15 \mathrm{~min}$. The $\%$ florescence was read at 10x sensivity (adjusted to bring readings of standard tubes within range) with primary filter 7- $60(365 \mathrm{~nm})$ and secondary filter $2 \mathrm{~A}+65 \mathrm{~A}$ $(500 \mathrm{~nm})$. The concentration of the standard phenylalanine was $0.05 \mathrm{mg} / \mathrm{ml}$.

\section{Statistical analysis}

Data collected were expressed as mean \pm standard deviation [SD], and the student't' test was use for analysis. Values of $p<0.05$ were regarded as significant.

\section{RESULTS}

Table 1 presents the results of treatments of aspartame and sucrose on serum total protein and blood glucose levels in rats. The results for the serum total protein levels in rats showed that there was significant $(\mathrm{P}<0.05)$ increase $(36 \%)$ in the aspartame treated rats, and a decrease $(20.2 \%)$ in the sucrose treated animals when compared to those seen in the controls. There was also significant decrease in the aspartame + sucrose treated group (25.5\%). However, relative to the sucrose treated animals, this value was non-significant, ie comparatively decreased by $4.4 \%$. However, comparing the values of the aspartame treated hosts with those of sucrose treated animals, the values of the sucrose treated rats were significantly lower, ie, comparatively decreased by $87.6 \%$.

The results of treatment of aspartame and sucrose on blood glucose levels in rats showed that the treatments with aspartame only led to significantly $(p<0.05)$ increase $(16.3 \%)$ while treatments with sucrose only led to significant increase $(34.3 \%)$ relative to those of the controls. There was also significant increase in the aspartame + sucrose treated (11.4\%). However, relative to the sucrose only animals, this value was significantly lower, ie comparatively decreases by $35 \%$. Also, comparing the values of the aspartame treated rats with those of sucrose treated animals; the value of the sucrose treated rats was higher, ie comparatively increased by $21.6 \%$.

Table 2 presents the results of treatments on hemoglobin and hemtocrit in rats. The results for the hemoglobin levels showed that there was significant $(P<0.05)$ increase $(9.6 \%)$ in the values of the aspartame 
treated rats and a decreased $(30.8 \%)$ in the sucrose treated animals, relative to the controls. There was also significant decreased $(35.6 \%)$ in values of the aspartame + Sucrose treated hosts relative to those seen in the control hosts. However, relative to the sucrose only animals, this value was significantly lower, ie, comparatively decreased by $3.6 \%$. Also, comparing the values of the aspartame treated rats with those of sucrose treated animals; the value of the sucrose treated rats was lower, and comparatively decreased by $44.7 \%$.

The results of treatments of aspartame and sucrose on hematocrit levels showed that there was significant $(\mathrm{P}<0.05)$ decrease $(60 \%)$ in values of the aspartame treated rats; decreased $(88.2 \%)$ in values of the sucrose treated animals, and a decrease $(96.7 \%)$ in values of the aspartame + Sucrose treated rats relative to those seen in the controls. However, relative to the sucrose treated rats, this values was significantly higher, and Comparatively increased by $4.5 \%$; and relative to the aspartame treated animals, this value was also significantly higher, that is Comparatively increased by $23.1 \%$. Also, comparing the values of the aspartame treated animals with those of sucrose treated hosts, the values of the sucrose treated hosts is lower, ie, comparatively decreased by $17.9 \%$.

Table 3 presents the results of treatments of aspartame and sucrose on brain tryptophan and phenylalanine levels in rats. The results for the brain trytophan levels showed that there was significant $(P<0.05)$ decrease $(66.6 \%)$ in values of the aspartame treated hosts and decrease $(91.9 \%)$ in values of the Sucrose treated animals. There was also significant decrease $(283.8 \%)$ in values of the aspartame + Sucrose treated animals. However, relative to the Sucrose only animals, this value was significantly lower, comparatively decreased by $100 \%$, comparing the values of the aspartame treated hosts with those of the sucrose treated animals, the value of the sucrose treated rats was lower, ie., comparatively decreased by $15.2 \%$.

The results of treatment of aspartame and sucrose on brain phenylalanine levels showed that there was significant $(P<0.05)$ increase $(49.2 \%)$ in values of the aspartame treated rats, and increase $(47.4 \%)$ in values of the sucrose treated group. There was also significant increase in values of the aspartame + Sucrose treated group $(66.4 \%)$ relative to those of the controls. However, relative to the sucrose only animals, this value was higher, comparatively increased by $36.2 \%$; and relative to the aspartame treated animals, this value was also higher ie., comparatively increased by $33.9 \%$. Also, comparing with those of the sucrose treated hosts with those of the sucrose treated rats, there was no significant difference between the values of the aspartame treated rats and sucrose treated hosts.

Table 1: Effect of aspartame and sucrose on serum total protein and blood glucose levels in rats.

\begin{tabular}{lrr}
\hline Treatment group $(\mathrm{N})$ & Serum total protein $(\mathrm{mg} / \mathrm{ml})$ & Blood glucose $\mathrm{mg} / \mathrm{dl})$ \\
\hline 1. Control & $10.78 \pm 0.46$ & $124.67 \pm 2.38$ \\
2. Aspartame & $16.83 \pm 0.85$ & $148.93 \pm 3.07$ \\
3. Sucrose & $8.97 \pm 0.37$ & $189.89 \pm 3.58$ \\
4. Aspartame + Sucrose & $8.59 \pm 0.34$ & $140.68 \pm 3.26$ \\
\hline
\end{tabular}

$\mathrm{N}=$ Number of rats per group $=4$, Values are expressed as mean \pm

SD. *Significantly different from control at $P<0.05$.

Table 2: Effect of aspartame and sucrose on hemoglobin and hematocrit levels in rats.

\begin{tabular}{lcc}
\hline Treatment group $(\mathrm{N})$ & Hemoglobin levels $(\mathrm{g} / \mathrm{dl})$ & Haematocrit levels $(\%)$ \\
\hline 1. Control & $14.89 \pm 0.48$ & $40.67 \pm 0.53$ \\
2. Aspartame & $16.47 \pm 0.57$ & $30.48 \pm 0.42$ \\
3. Sucrose & $11.38 \pm 0.39$ & $25.86 \pm 0.37$ \\
4. Aspartame + Sucrose & $10.98 \pm 0.34$ & $24.74 \pm 0.30$ \\
\hline
\end{tabular}

$\mathrm{N}=$ Number of rats per group $=4$, Values are expressed as means \pm

SD. *significantly different from control at $P<0.05$.

Table 3: Effect of aspartame and sucrose on brain tryptophan and brain phenylalanine levels on rats.

\begin{tabular}{llc}
\hline Treatment group $(\mathrm{N})$ & Brain tryptophan levels $(\mathrm{mg} / \mathrm{dl})$ & Brain phenylalanine $(\mathrm{mg} / \mathrm{dl})$ \\
\hline 1. Control & $5.68 \pm 0.47$ & $5.49 \pm 0.41$ \\
2. Aspartame & $3.41 \pm 0.38$ & $10.81 \pm 0.73$ \\
3. Sucrose & $2.96 \pm 0.33$ & $10.44 \pm 0.57$ \\
4. Aspartame + Sucrose & $1.48 \pm 0.27$ & $16.36 \pm 0.87$ \\
\hline
\end{tabular}

$\mathrm{N}=$ Number of rats per group $=4$, Values are expressed as means \pm

SD. *significantly different from control at $\mathrm{P}<0.05$. 


\section{DISCUSSION}

In this study, co-administration of aspartame and sucrose increased the blood glucose and brain phenylalanine levels but decreased total protein hemoglobin, haematocrit and tryptophan levels of the rats. The increase in blood glucose levels could be attributed to inhibition of glucose uptake by the hepatic tissues due to product inhibition of hexokinase. Liver cells contain an isoform of hexokinase called glucokinase, which is not fully active at the physiological ranges of blood glucose, due to its lower affinity for glucose than does hexokinase. Additionally, glucokinase is not inhibited by its product glucose-6phosphate (G6P), whereas, hexokinase is inhibited by G6P (Fishbein, 1982; Goldman et al, 1986, Smith, 1991). Thus, under conditions of high blood glucose, liver glucose could be high and the activity of glucokinase be elevated, and the G6P produced by glucokinase could be rapidly converted to G1P by phosphoglucomutase, and incorporated into glycogen (Ross et al, 1988; Barker et al, 1993, Young et al 1994), resulting in inhibition of glucose uptake by hepatic tissues.

The decrease in serum total protein levels could be attributed to the activation of tyrosine kinase, which resulted in ligand-receptor interaction (ie intracellular events), leading to protein phosphorylation. Protein phosphosylations by tyrosine kinase change enzyme activities and protein conformations, resulting in alteration in cellular activity and changes in the program of gene expressed within the responding cells, which could result in inhibition of protein synthesis, leading to anemia and fluid retention (Ross et al, 1988; Volavka et al, 1990).

The decrease in hemoglobin, haematocrit and tryptophan levels could be attributed to inhibition of tyrosine phosphatases, particularly, cluster determinant - 45 (CD-45), protein of $\mathrm{T}$ cells and macrophages. Protein tyrosine phosphatase (PTP), particularly, leukocytes common antigen protein-cluster determinant, CD45, is involved in the regulation of the tyrosine kinase activity of leukocytes in T cells (Rabble et al, 1996). It is suspected that CD45 dephosphorylates a regulatory tyrosine phosphorylation site in the C-terminals (which are mostly hydrophobic) of leukocytes, thereby increasing the activity of leukocytes towards its substrates. (Dede and Kagbo,2002)The loss of a functional phosphatase involved in regulating growth promoting signals could lead to neoplasia (Rabble et al, 1996). However, substantial evidence links both tyrosine and serine/threonine phosphorylation with increased cellular growth, proliferation and differentiation (Vanpraag, 1986; Rablle et al, 1996). Thus, removal of the incorporated phosphates must be a necessary event in order to turn off the proliferative signals. This may appear to suggest that phosphates may function as anti-oncogenes or growth suppressor genes. However, examples are known where dephosphorylation may be required for promotion of cell growth. Therefore, it is deficient to envision all phosphates as being tumour suppressor genes (Rabble et al, 1996).

The hematological parameters(i.e.hemoglobin and hematocrit) values provide information on the general state of the blood chemisty. The metabolic intermediates of aspartame and sucrose such as hydroxyl radicals $(. \mathrm{OH})$ have been found to alter blood chemistry and induced anemia by causing bone marrow depression through inadequate production of red blood cells and white blood cells, leading to DNA damage and alteration in DNA function (Rabble et al, 1996; Dede and Kagbe, 2002).

The increase in brain phenylalanine levels could be attributed to activation of adenylate cyclase, which modulated receptors (ie, G-protien coupled receptorsGPCRs) that activated the enzyme, leading to the production of CAMP as the second messenger. Increases in the production of cAMP leads to an increase in the activity of protein kinase $A$ (PKA), thus stimulating adrenergic receptors. Also, increase in cAMP leads to the activation of ion channels, resulting in opening of $\mathrm{Na}^{+} / \mathrm{Ca}^{2+}$ channels, leading to hypopolarization of the cells (Smith, 1991). The amino sequence of the tyrosine kinase are highly conserved with those of CAMP-dependent protein kinase A (PKA) within the ATP binding and substrate binding regions. This ligand binding penetrated the plasma membrane and migrated to the nucleus where the ligand receptor complex directly affected gene transcription. Many receptors that have intrinsic tyrosine kinase activity as well as the tyrosine kinases that are associated with cell surface receptors contain tyrosine residue, that upon phosphorylation, interact with other proteins of the signaling cascade.

Also, receptors with intrinsic tyrosine kinase activity are capable of autophosphorylation as well as phosphorylation of other substrates. However, hormone receptors are bi-functional, capable of binding hormones as well as directly activating gene transcription. These hormones are capable of free penetrating the hydrophobic plasma membrane, and upon binding ligand the hormone - receptor complex translocates to the nucleus and bind to specific DNA sequence called hormone response element (HRE). The binding of the complex to an HRE results in altered transcription rates of the associated gene. Thus, interaction of a refined carbohydrate such as sucrose with phenylalanine increased the tyrosine levels due to inhibition of gene transcription which had led to conversion of phenyalanine to tyrosine (Vanpraag, 1986; Ross et al, 1988).

The decrease in tryptophan levels could be attributed to activation of adenylate cyclase. The catecholamines - dopamine, noradrenaline and adrenaline are synthesized from phenylalanine and tyrosine through the action of phenylalanine hydroxylase. Briefly, the tyrosine transported to catecholamine - secreting neurons and converted to catecholamines, which bound to $\beta$-adrenergic receptors, which coupled intracellular G-proteins, resulting in activation of $\beta$-adrenergic pathways and monoamineoxidase, leading to increased synthesis of a adrenaline, which has been directly linked to aggression and violent behaviours (Ross et al, 1988). The activation of $\beta$-adrenergic pathway had led to inhibition of serotenergic pathway, leading to reduced serotonin level (Ross etal, 1988) due to reduced trytophan levels owing to inhibition of decarboxylation of tryptophan. Serotonin is synthesized by the hydroxylation and 
decarboxylaytion of tryptophan. Most of the serotonin $(5 \mathrm{HT})$ receptors, particularly the $5 \mathrm{HT}_{6}$ and $5 \mathrm{HT}_{7}$ are coupled to G-protiens that affect the activities of adenylate cyclase or phopholipase cy, which mediate platelet aggregation and smooth muscle contraction. These receptors are distributed throughout the limbic system of the brain and have (mostly $5 \mathrm{HT}_{6}$ ) high affinity for antidepressant drugs. Thus, the binding of these receptors to aspartame and sucrose, inhibited serotenergic pathways, leading to reduced serotonin levels, in parts, due to activation of adenylate cyclase, leading to increased tyrosine levels in the brain. The effects of reduced serotonin are felt most prominently in the cardiovascular system, respiratory system and the intestines, leading to increased rate of heartbeat, breathing and contraction of smooth muscles, which are often observed during aggression and violent behaviours (VAnpraag, 1986; Ross et al, 1988). Since dietary tryptophan acts as a precursor for serotonin synthesis, reduced levels of tryptophan could result in a reduction of brain serotonin levels, and has been directly linked with both hyperactive and aggressive behaviours (Volavka etal, 1990)

Aspartame and sucrose seemed greatly to increase their restless and destructive behaviour of susceptible individuals. This might suggest that artificial food additives do not appear to be immunological but rather pharmacological or toxic in type; and may act as haptens and after attaching themselves to macromolecules, could become antigenic, thus, producing an allergic reaction (or an elevated sensitivity) in susceptive individuals. This paper, therefore, calls for caution in the use of aspartame and sucrose or other sweet food additives. The young peoples with developing nervous system seem to be particularly vulnerable, because of immaturity of their enzymatic detoxifying mechanism; incomplete function of excretory organs, low level of plasma protein capable of binding toxic chemicals and incomplete development of physiological barriers (Young et al, 1994). These foods therefore seemed greatly to increase their restless and destructive behaviour of susceptible individuals. These alterations had led to changes in behaviours including aggressive and violent behaviours.

Conclusively, consumption of aspartame and sucrose have been found to inhibit protein and leukocytes synthesis, resulting in anemia by causing bone marrow hypoplasia, DNA dysfunction, aggressive and violent behaviour as well as reactive hypoglycemia in rats. This has been linked with diverse personality and psychiatric disorders such as neuroses, panic attacks, agoraphobia and Schizophrenic episodes as well as neuronal disorders. These foods therefore seemed greatly to increase their restless and destructive behaviour of susceptible individuals. These alterations had led to changes in behaviours including aggressive and violent behaviours.

\section{REFERENCES}

Davidson, L. and Henry, J. B., 1979. Estimation of tryptophan in clinical diagnosis by laboratory methods. $16^{\text {th }}$ Edition, Davidson, $L$ and Henry, J. B. eds. W. B. Saunders, Philadelphia, pp 157-159.
Dede, E. B, kagbo, H. O., 2002. A Study on the acute toxicological effect of commercial diesel fuel in Nigeria in rats (Ratus ratus) using haematological parameters. J. Applied Sci. Environ. Mgt. 6: 84-86.

Fishbein, D., 1982. The Contribution of refined carbohydrate consumption to maladaptive behaviours. J. Orthomolecular psychiatry 11(1). $1-4$.

Galler, J. R., 1986. Malnutrition-a neglected cause of learning failure. Postgrad. Med. 80:225-230.

Gornall, A. G, Bardawill, C. J, and Maxima D., 1947. Determination of Serum proteins by the means of the biuret reaction. Biol-chem 177:751-766.

Goldman, F. J., 1986. Behavioral effects of sucrose in preschool children. J. Abnormal child psychology. 14 (4): 565-577.

Lowry, O. H., Rosenbrough, N. J, Farr, A. L, and Randall, R. J. (1951). Protein measurement with the folin phenal reagent. J. Biol. Chem. 193: 265-275.

Ross, A., 1988. Monoamines, glucose metabolism, aggression toward self and others. Int. J. Neurosci, 41(3-4): 261-264.

Rabble, G. K. and Wong, O., 1996. Leukemia mortality by cell type in Petroleum workers with potential Environ. Health Perspect 104: 1381-1392. exposure to benzene.

Smith, J. M., 1991. Adverse reactions to foods and drug additives. Eur. J. Clin. Nutr. 45 (Suppll):17-21.

Taylor, H. E., 1989. Analysis of blood and blood glucose in Clinical Chemistry. $4^{\text {th }}$ Edition. Taylor, HE (ED), John Wiley and Sons, New York. Pp 267 288.

Wynn, S. W. I., 1994. The association of maternal social class with maternal diet and the dimension of babies in the population of London women. Nutrition and Health 9: $303-313$.

Ward, N. I., Soul/Sbury, K. A. and Zeitel, V. H., 1990. The influence of the additive tartazine on the Zinc status of hyperactive children. J. Nutr. Med. 1: $51-57$.

Van Praag, H. M., 1986. Affective disorders and aggressive disorders: Evidence of common biochemical metabolism. Suicide life threat Behaviour, 16 (2): 103-132.

Volavka, J., 1990. Tryptophan treatment of aggressive psychiatric in-patients. Biological Psychiatry, 28 (8): 728-732.

Virkkunen, M., 1986. Reactive hypoglycemic tendency among habitually violent offenders. J. Nutr. Rev (Suppl): 94-103.

Young, E., 1994. A population study of food intolerance. The lancet, 243: 1127-1129. 